\title{
Marmites rituelles et autochtonie à Ponérihouen (Nouvelle-Calédonie)
}

Isabelle Leblic

\section{(2) OpenEdition \\ 12 Journals}

Édition électronique

URL : https://journals.openedition.org/tc/352

DOI : $10.4000 /$ tc. 352

ISSN : 1952-420X

Éditeur

Éditions de l'EHESS

\section{Édition imprimée}

Date de publication : 1 juillet 1999

ISSN : 0248-6016

\section{Référence électronique}

Isabelle Leblic, « Marmites rituelles et autochtonie à Ponérihouen (Nouvelle-Calédonie) », Techniques \& Culture [En ligne], 33 | 1999, mis en ligne le 26 octobre 2005, consulté le 29 septembre 2022. URL :

http://journals.openedition.org/tc/352 ; DOI : https://doi.org/10.4000/tc.352

Ce document a été généré automatiquement le 29 septembre 2022.

Tous droits réservés 


\section{Marmites rituelles et autochtonie à Ponérihouen (Nouvelle-Calédonie)}

Isabelle Leblic 